ROCZNIKI TEOLOGICZNE

Tom LXVI, zeszyt 1 - 2019

DOI:http://dx.doi.org/10.18290/rt.2019.66.1-8

MARIAN Z. STEPULAK

\title{
PROBLEMY ETYCZNO-ZAWODOWE PRACOWNIKA SOCJALNEGO W PRACY Z OSOBAMI BEZDOMNYMI
}

\author{
ETHICAL AND VOCATIONAL PROBLEMS OF A SOCIAL WORKER \\ IN WORKING WITH HOMELESS PEOPLE
}

\begin{abstract}
A b s t r a c t. In this article, the issue of homelessness in the aspect of its definition, causes and typology was subjected to scientific reflection at the beginning. Subsequently, the subject of scientific analysis became the ethical and moral problems of a social worker in interpersonal relations with the homeless. Ethical principles and norms are first of all in the Code of Ethics of Social Workers and Social Assistance Workers of the Polish Federation and in the Ethical Code of the Polish Society of Social Workers. In addition, a social worker must achieve many goals. One of such goals is continuous ethical and moral improvement as well as personality improvement. The second area of formation of a social worker is professional qualifications, which assume the following principles: a) the principle of operation for the good and respect of the charges; b) the principle of fidelity and responsibility; c) the principle of honesty and integrity; d) the principle of justice; e) the principle of respect for human rights and human dignity.
\end{abstract}

Key words: professional competences; moral qualification; homeless person; social worker; interpersonal relations.

W potocznym spojrzeniu na zjawisko bezdomności można dostrzec ogromną dychotomię postaw. Część społeczeństwa bowiem postrzega bezdomność w kategoriach współczucia i litości, a druga poprzez radykalne odrzucenie

Ks. dr hab. Marian Z. STEPULAK, prof. PWSZ w Płocku - Państwowa Wyższa Szkoła Zawodowa w Płocku, Wydział Nauk Humanistycznych i Społecznych, Zakład Pedagogiki Specjalnej i Resocjalizacji, 09-402 Płock, ul. Gałczyńskiego 28; adres do korespondencji - e-mail: marian.stepulak@o2.pl 
i lęk. Zdarza się również, iż niektórzy traktują bezdomnych w sensie romantycznym, interpretując ich sytuację $\mathrm{w}$ aspekcie wolnego wyboru swobody i wolności. Patrzą na bezdomnego jako człowieka wyzwolonego od obowiązujących konwencji, norm społecznych i umów ${ }^{1}$. Powyższe konteksty postrzegania bezdomności i bezdomnych nie eliminują jednak tego społecznego zjawiska. Podejmowane są zatem różne działania w wymiarze instytucjonalnym i pozainstytucjonalnym służące pomocy osobom bezdomnym. $\mathrm{W}$ obu przypadkach znaczące miejsce wypełniają pracownicy socjalni. Podstawą skutecznych działań jest zaufanie na linii: pracownik socjalny-osoba bezdomna. Zaufanie stanowi naturalne wyposażenie ludzkiej osoby, dlatego też pracownik socjalny, wchodząc $w$ relacje $\mathrm{z}$ podopiecznym, $\mathrm{z}$ natury rzeczy zakłada postawę zaufania. Powstała $w$ ten sposób atmosfera zaufania i poszanowania prywatności i intymności warunkuje z kolei skuteczność aktywności zawodowej pracownika socjalnego ${ }^{2}$.

Zaufanie jest fundamentalnym warunkiem nawiązania kontaktu z osobą bezdomną, która bardzo często jest dotknięta osamotnieniem. Będąc w takim stanie, osoby bezdomne mają tendencję do izolacji od innych osób, osłabienia więzi interpersonalnych oraz wszelkiej komunikacji o charakterze werbalnym i pozawerbalnym. W sytuacji samotności i osamotnienia osoba bezdomna staje się skrajnie nieufna, z czego musi sobie zdawać sprawę pracownik socjalny. Winien zatem podjąć odpowiednie działania, aby takiej sytuacji skutecznie zaradzić. W tym przypadku potrzebne są jednak wysokie kompetencje zawodowe i kwalifikacje osobowościowe i moralne ${ }^{3}$.

$\mathrm{W}$ artykule niniejszym zostanie zatem podjęta naukowa refleksja nad zagadnieniem bezdomności i osób bezdomnych. W następnej kolejności zostaną przeprowadzone analizy wybranych, etycznych problemów pracownika socjalnego w relacjach interpersonalnych z bezdomnymi oraz zawodowe problemy pracownika socjalnego $\mathrm{w}$ relacjach interpersonalnych $\mathrm{z}$ takimi osobami.

\footnotetext{
1 M. PIECHOwicz, Bezdomność jako problem społeczny i indywidualny - możliwości profilaktyki, „Resocjalizacja Polska” 2012, nr 3, s. 327.

2 M.Z. STEPULAK, Psycholog jako zawód zaufania społecznego, TN KUL, Lublin 2007, s. 139.

${ }^{3}$ M.Z. STEPUlaK, W. KowAlski, Zjawisko bezdomności $w$ świetle teorii i badań $w$ Lublinie i województwie lubelskim, Innovatio Press Wydawnictwo Naukowe Wyższej Szkoły Ekonomii i Innowacji w Lublinie, Lublin 2015, s. 108.
} 


\section{PROBLEMATYKA BEZDOMNOŚCI}

Dla pełnej analizy problematyki bezdomności niezbędne jest dokonanie naukowej refleksji nad definicją bezdomności. Najczęściej w literaturze przedmiotu przywoływana jest definicja zawarta w Ustawie o pomocy społecznej z 2004 roku: „Osoba bezdomna - osoba niezamieszkująca w lokalu mieszkalnym w rozumieniu przepisów o ochronie praw lokatorów i mieszkaniowym zasobie gminy i niezameldowana na pobyt stały, w rozumieniu przepisów o ewidencji ludności i dowodach osobistych, a także osoba niezamieszkująca w lokalu mieszkalnym i zameldowana na pobyt stały w lokalu, w którym nie ma możliwości zamieszkania" 4 .

Biorąc pod uwagę pojawiające się w literaturze definicje bezdomności można by podzielić je na dwie zasadnicze grupy:

- Pierwsza grupa definicji odnosi się głównie do braku mieszkania bądź schronienia oraz wyodrębnienia osób, które są zaliczone pod tym kątem do kategorii bezdomnych.

- Druga grupa definicji akcentuje takie wymiary sytuacji bezdomności, jak: predyspozycje psychiczne osób nią dotkniętych, sposób ich życia codziennego, odrzucenie norm i wartości, deprywacja w zakresie podstawowych potrzeb człowieka ${ }^{5}$.

W drugim znaczeniu można powiedzieć, iż współczesny człowiek staje się społecznie „bezdomny” wobec relatywizmu, względności wszystkich norm i wartości. Bezdomność w znaczeniu psychicznym i duchowym może odczuwać emigrant mieszkający w obcym mu kulturowo kraju, ale także człowiek żyjący w znienawidzonym przez siebie ustroju politycznym i społecznym ${ }^{6}$.

W niektórych definicjach pojawia się termin ,anomia"7. Termin ten oznacza proces wycofania się z życia społecznego osób dotkniętych bezdomnością. „Anomia może rodzić się na bazie jednostkowych problemów adaptacyjnych, albo też może wynikać z patologii samego systemu społecznego - jego instytucji, ideologii, prawa czy więzi społecznych. Stan anomii charakteryzuje się poczuciem zagubienia, poczuciem bezpowrotnej utraty norm moralnych, także

${ }^{4}$ Ustawa z dnia 12 marca 2004 r. o pomocy społecznej (Dz.U. 2004 Nr 64 poz. 593).

5 A. LECH, Świat społeczny bezdomnych i jego legitymizacje, Wydawnictwo Naukowe „Śląsk”, Katowice 2007, s. 32-33; M. JAŹDZIKowski, Syndrom bezdomności, „Świat Problemów” 2000, nr 6(89), s. 4-7.

${ }^{6}$ Tamże, s. 35.

${ }^{7}$ Twórcą terminu ,anomia” był E. Durkheim. Zob. E. DuRKhEIM, Próba określenia zjawisk religijnych, „Biblioteka Samokształcenia”, Warszawa 1903. 
braku poczucia bezpieczeństwa, niepewności, ambiwalencji emocjonalno-uczuciowej oraz poczuciem obcości"8. Negatywnym skutkiem anomii jest także dezorientacja, alienacja oraz zupełne zagubienie się bezdomnej osoby ${ }^{9}$.

Istotnym problemem $\mathrm{w}$ definiowaniu pojęcia bezdomności jest znalezienie złotego środka pomiędzy „obiektywnymi wskaźnikami bezdomności a osobistym poczuciem braku własnego bezpiecznego miejsca na ziemi"10.

Definicja bezdomności stała się przedmiotem zainteresowania wielu dziedzin i dyscyplin naukowych i być może kwestia jej holistycznego i jednoznacznego określenia może sprawiać wiele problemów natury metodologicznej ${ }^{11}$.

Bardzo ważnym zagadnieniem dla zjawiska bezdomności jest określenie jej przyczyn. Współcześnie zakłada się istnienie następujących przyczyn bezdomności:

- Przyczyny społeczne. W tym przypadku w grę wchodzą sytuacje społeczno-ekonomiczne, których efektem jest: wzrost bezrobocia, a także likwidacja hoteli robotniczych i innych tego typu lokali. Brak wolnych miejsc w szpitalach i zakładach opiekuńczych dla osób z zaburzeniami psychicznymi lub osób niepełnosprawnych w różnych obszarach. Brak wolnych miejsc dla rencistów, emerytów i osób w podeszłym wieku w domach pomocy społecznej. Do tego dochodzi brak opieki nad wychowankami domów dziecka po ukończeniu 18 roku życia i brak zapewnienia im mieszkania. Brak ośrodków dla osób zagrożonych wirusem HIV.

- Przyczyny związane z patologiami i chorobami, do których należy zaliczyć: alkoholizm i inne uzależnienia, przestępczość, odrzucenie lub brak opieki ze strony najbliższych, rozwód albo trwały rozpad małżeństwa oraz innych więzi formalnych i nieformalnych, w przypadku kobiet z dziećmi alkoholizm i psychopatia męża.

- Przyczyny natury psychologicznej, spośród wielu z nich można wskazać: świadomy wybór innej strategii życia i odmiennego systemu wartości.

\footnotetext{
${ }^{8}$ M. DudA, Bezdomność - wyzwanie moralne spoteczeństwa, w: Przestrzenie pracy socjalnej, red. J. Stala, Biblos, Tarnów 2010, s. 376; za: M.Z. STEPULAK, Wybrane problemy etyczno-zawodowe w pracy socjalnej, Innovatio Press Wydawnictwo Naukowe Wyższej Szkoły Ekonomii i Innowacji w Lublinie, Lublin 2012, s. 23.

9 J. PAŁCZYŃSKI, Anomia, w: Słownik psychologii, red. J. Siuta, Wydawnictwo Zielona Sowa, Kraków 2005, s. 27.

10 I. PosPisZYL, Patologie społeczne, Wydawnictwo Naukowe PWN, Warszawa 2009, s. 294.

${ }^{11}$ M.Z. STEPUlaK, W. Kowalski, Zjawisko bezdomności w świetle teorii i badań w Lublinie i województwie lubelskim, s. 20; M. KuSY, Świat społeczny bezdomnych kobiet, „Praca Socjalna" 27(2012), s. 140-146.
} 
- Przyczyny prawne. W tym przypadku chodzi o ustawę, która dawała możliwość eksmitowania lokatora za długi i zaległości w opłatach czynszowych ${ }^{12}$.

Przyczyny bezdomności mogą być ujmowane w aspekcie czynników obiektywnych i subiektywnych. Powyższe, dwie grupy czynników całościowo odkrywają istotę bezdomności. Znaczącmi elementami w procesie bezdomności są: czas jego trwania, siła oddziaływania, dynamika przebiegu procesu, a także indywidualne zdarzenia o charakterze losowym. Do czynników obiektywnych zalicza się różnorakie przekształcenia cywilizacyjne, postęp techniczny i technologiczny, rozwój gospodarczy, wolny rynek, mechanizmy konkurencji oraz proces urbanizacji i industrializacji. Natomiast do czynników subiektywnych można zaliczyć: upadek społeczno-moralny osoby i społeczeństwa, odrzucenie norm społecznych i rodzinnych, patologie (przestępczość, alkoholizm, hazard, prostytucja czy też narkomania oraz inne uzależnienia) ${ }^{13}$.

„Biorąc pod uwagę wymienione przyczyny bezdomności można mówić o pewnym psychologicznym mechanizmie. Niekiedy nazywa się go syndromem bezdomności. Polega to na tym, że osoba bezdomna w pełni przystosowuje się do warunków bezdomności. Oznacza to, że taka osoba stara się zająć wygodne miejsce w schronisku, nawet podjąć pracę i płacić za swój pobyt. Jednakże ten syndrom może prowadzić do utraty motywacji w podejmowaniu prób wyjścia z bezdomności" ${ }^{14}$.

W sytuacji minionego ustroju społeczno-politycznego w Polsce do 1981 roku wszelkie badania i dane statystyczne nie uwzględniały istnienia zjawiska bezdomności. Uznawano, iż bezdomności nie ma. „Dopiero w późniejszym czasie władze, naciskane $\mathrm{z}$ różnych stron przez zainteresowane problemem środowiska i instytucje, zezwoliły na zarejestrowanie Towarzystwa Pomocy im. Adama Chmielowskiego, obecnie im. św. Brata Alberta. Po 1989 roku zaczęto zwracać większą uwagę na zjawisko bezdomności. Dzisiaj istnieje szereg instytucji i organizacji pozarządowych zajmujących się problemem bezdomności”"15.

12 B. KULKA, Ludzie bezdomni - jak możemy im pomóc? w: Środowiska specjalnej troski, red. M. Kalinowski, Wydawnictwo POLIHYMNIA, Lublin 2003, s. 45-46; cyt. za: M.Z. STEPULAK, Wybrane problemy etyczno-zawodowe w pracy socjalnej, s. 24-26.

${ }^{13}$ L. Stankiewicz, Zrozumieć bezdomność, Wydawnictwo UWM, Olsztyn 2002, s. 66; cyt. za: M.Z. STEPULAK, W. KowALSKI, Zjawisko bezdomności w świetle teorii i badań w Lublinie $i$ województwie lubelskim, s. 24.

14 Tamże, s. 24; A. CHAŃKO, O potrzebie poczucia koherencji u osób bezdomnych, „Praca Socjalna" 28(2013), s. 116-120.

15 Tamże, s. 24; I. SIERPOwSKA, Sytuacja prawna osoby bezdomnej w Polsce, „Praca Socjalna” 26(2011), s. 84-105. 
Dane statystyczne dotyczące bezdomności są mało precyzyjne. Podczas ogólnopolskiej akcji liczenia osób bezdomnych z nocy 8 na 9 lutego 2017 roku, którą przeprowadza się co dwa lata, zarejestrowano ponad 33,4 tys. bezdomnych. W porównaniu z poprzednim badaniem (z 2015 roku) liczba osób bezdomnych zmalała o 2,7 tys. Główne przyczyny bezdomności to eksmisje i konflikty rodzinne. Ponad 83,5 proc. bezdomnych to mężczyźni. Powyższą akcję przeprowadzono po raz czwarty. Była ona koordynowana przez Ministerstwo Rodziny, Pracy i Polityki Społecznej. Według informacji minister Elżbiety Rafalskiej, w porównaniu z badaniem przeprowadzonym w 2015 r., liczba osób bezdomnych zmalała o 2753 osoby. We wspomnianym już wcześniej roku 2017, w momencie realizacji badania (liczenia bezdomnych), zdiagnozowano 33408 osób bezdomnych, z czego 83,55 proc. stanowili mężczyźni (27 911 osób), natomiast 16,45 proc. - kobiety (5497 osób) ${ }^{16}$. Należy jednak dodać, iż jedynym adekwatnym źródłem, które dostarczyć mogłoby informacji o liczbie bezdomnych, jest liczba osób, którym formalnie udzielona została pomoc przez ośrodki pomocy społecznej.

Wśród wielu typologii bezdomności wyróżnia się następujące jej rodzaje:

- Bezdomność oniryczna (związany ze snem, odnoszący się do niego); jest to stan powstały na kształt marzenia sennego, dotyka on osoby pozbawione wyobrażenia domu jako spójnego elementu psychiki. Bezdomność tego typu odnosi się przede wszystkim do osób wychowywanych w domach dziecka.

- Bezdomność normatywna bierze pod uwagę wymiar aksjologiczny. Występuje ona wówczas, kiedy osoba bezdomna nie wynosi z systemu domowo- rodzinnego wartości, które by ją tam zakorzeniały i jest w stanie swoistej anomii.

- Bezdomność społeczna, ma ona miejsce w sytuacji, kiedy ktoś w miejscu zamieszkania odczuwa podstawowy brak więzi emocjonalnych, uczuciowych i społecznych z powodu własnej samotności, czy też przebywania w rodzinie dysfunkcyjnej lub patologicznej. Osoba taka jest pozbawiona poczucia bezpieczeństwa, zrozumienia i przynależności.

- Bezdomność funkcjonalna to z kolei stan, w którym warunki domowe nie pozwalają na zaspokojenie elementarnych potrzeb jednostki.

Bezdomność materialna i fizyczna odnosi się do sytuacji, w której osoba pozbawiona jest miejsca, w którym może się schronić i odpocząc ${ }^{17}$.

\footnotetext{
16 www.polsatnews.pl/wiadomosc/2017-03-09 (dostęp: 09.08.2018).

17 A. KinAL, Bezdomność jako wyzwanie dla społeczności lokalnej, „Rocznik Lubuski” 29(2003), cz. 1, s. 193-206; P. GIEREK, O ludziach niechcianych - wykluczonych i marginalizowanych, „Praca Socjalna” 25(2010), s. 22-53.
} 
Powyższy kontekst wskazuje, iż bezdomność jest zjawiskiem o bardzo rozległym i skomplikowanym polu poznawczym. Wymaga zatem intensywnej pracy badawczej i praktycznej.

\section{ETYCZNE PROBLEMY PRACOWNIKA SOCJALNEGO W RELACJACH INTERPERSONALNYCH Z BEZDOMNYMI}

Problem bezdomności od dawna towarzyszy człowiekowi. Współcześnie jednak nabrał szczególnego znaczenia, zwłaszcza w krajach wysoko cywilizowanych i bogatych. Stał się on bowiem dla niektórych rządzących „wstydliwym problemem", kiedy nie udaje się go rozwiązać. Ludzie bogatsi nie przejawiają empatii i współczucia ludziom bezdomnym i biednym. Przełom XX i XXI wieku generuje w bardzo dynamiczny sposób zjawisko nierówności społecznych ${ }^{18}$. W tej sytuacji pojawiają się nowe pojęcia: poverty tourism, slum tourism, slumming, poorism - wszystkie z wymienionych terminów odsyłają do coraz popularniejszej obecnie formuły podróżowania, która w Polsce została określona mianem bieda-turystyki. Ten oryginalny rodzaj podróżowania polega na odwiedzaniu miejsc dotkniętych skrajnym ubóstwem i bezdomnością w celu obserwowania życia mieszkańców enklaw nędzy, szczególnie tych zamieszkujących kraje trzeciego świata, ale i również bogatych państw europejskich. Nie jest to zjawisko nowe, aczkolwiek współcześnie przybiera na sile. Slum tourism, organizowany przez czarnoskórych mieszkańców, stanowił przy końcu XX stulecia próbę edukowania białych obywateli RPA (i nie tylko ich - albowiem przyciągał również turystów zagranicznych) - a wycieczki po terenach tzw. town ship miały przybliżać i konkretyzować dramat toczącej się tam ludzkiej egzystencji. W latach 90. XX wieku pojawiła się nawet swoista moda na slum tourism, przez co samo zjawisko szybko zaczęło się komercjalizować - niestety, proces ten trwa do dziś. Początkowo była to rozrywka dla wybranych, czyli tych, którym zasobność portfela pozwalała na odwiedzenie najdalszych zakątków świata, z czasem stała się atrakcją dostępną niemal dla każdego ${ }^{19}$.

\footnotetext{
${ }^{18}$ Por. J. KLEBAniuk, Fenomen nierówności społecznych, ENETEIA, Wydawnictwo Psychologii i Kultury, Warszawa 2007; J. KLEBANIUK, Oblicza nierówności społecznych, ENETEIA, Wydawnictwo Psychologii i Kultury, Warszawa 2007a.

19 D. PodgóRska-Jachnik, Praca socjalna z osobami bezdomnymi, Centrum Rozwoju Zasobów Ludzkich, Warszawa 2014, s. 141-145.
} 
Ten bardzo specyficzny rodzaj podróżowania stał się między innymi powodem do zwrócenia uwagi poszczególnych rządów i instytucji pozarządowych do permanentnego kształtowania wrażliwości moralnej u pracowników socjalnych, ze szczególnym uwzględnieniem ich pracy $\mathrm{z}$ osobami bezdomnymi. W tym kontekście ważne jest odniesienie się do norm regulujących zachowanie pracowników socjalnych. Chodzi tutaj w szczególny sposób o dobro osób, które są odbiorcami działań zawodowych specjalisty z obszaru działań socjalnych ${ }^{20}$.

Kodeks Etyczny Pracowników Socjalnych i Pracowników Pomocy Społecznej Polskiej Federacji oraz Kodeks Etyczny Polskiego Towarzystwa Pracowników Socjalnych wymienia podstawowe kwalifikacje moralne pracownika socjalnego w dziale II pt. Odpowiedzialność etyczna pracownika wobec klienta ${ }^{21}$ :

„1. Pracownik zobowiązany jest do poszanowania godności klienta i jego prawa do samostanowienia.

2. Pracownik jest zobowiązany do równego traktowania klientów bez względu na wiek, płeć, stan cywilny, orientację seksualną, narodowość, wyznanie, przekonania polityczne, stan zdrowia, rasę, kolor skóry oraz inne preferencje i cechy osobiste.

3. Pracownik zobowiązany jest wykazać zaangażowanie na rzecz wszechstronnej pomocy klientowi w rozwiązywaniu jego trudności życiowych oraz wykorzystać w tym celu swoją wiedzę, umiejętności zawodowe oraz kompetencje.

4. Pracownik powinien - stosownie do możliwości klienta - wzmacniać jego wysiłki na rzecz życiowego usamodzielnienia.

5. Pracownik zobowiązany jest do udzielenia klientowi pełnej informacji na temat dostępnych świadczeń.

6. Pracownik winien zasięgnąć konsultacji współpracowników i zwierzchników w przypadku, gdy leży to w żywotnym interesie klienta.

7. Pracownik - za zgodą klienta - ma prawo zaprzestać świadczenia pomocy, gdy wyczerpane zostały przewidziane prawem świadczenia lub gdy takie świadczenia nie są już potrzebne.

8. Pracownik zobowiązany jest do zachowania w tajemnicy informacji uzyskanych od klienta w toku czynności zawodowych".

Codzienna praktyka wyraźnie wskazuje, iż pracownik socjalny miewa duże trudności związane z działaniem na rzecz walki z bieda-turystyką, poszanowa-

\footnotetext{
${ }^{20}$ K. SIKORA, Dobro odbiorcy w kodeksach etyczno-zawodowych psychologów, „Roczniki Psychologiczne" 16(2013), nr 4, s. 587.

${ }^{21} \mathrm{http}: / /$ ptps.ops.pl/kodeks_etyczny.htm (dostęp: 08.08.2018); M.Z. STEPULAK, Wybrane problemy, s. 78-79.
} 
niem godności podopiecznych, równego ich traktowania, z zaangażowaniem w pracę, dyskrecją i zachowywaniem tajemnicy zawodowej.

Uwzględniając powyższy kontekst naukowej refleksji nad zagadnieniem bezdomności można dojść do wniosku, iż nawiązywanie adekwatnej relacji interpersonalnej z osobami bezdomnymi przysparza wielu problemów nie tylko natury zawodowej, ale również etyczno-moralnej. Pracownik socjalny, aby mógł sprostać tej trudnej sytuacji, musi podjąć i zrealizować następujące cele:

- ciągle nabywać umiejętności głębokiej analizy i oceny zjawisk w kontekście bezdomności, wymagających świadczenia pomocy społecznej oraz podstawowych kompetencji do uzyskania tychże świadczeń, jest to ważne w sytuacji dynamicznych zmian społecznych i gospodarczych;

- nauczyć się generowania i realizowania nowych form pomocy osobom bezdomnym oraz posiąść kwalifikacje potrzebne do organizowania nowoczesnych instytucji, mogących takiej pomocy udzielać;

- udzielanie adekwatnych informacji organizowania pomocy w rozwiązywaniu różnorodnych problemów związanych z bezdomnością;

- profesjonalne przygotowanie do prowadzenia skutecznego poradnictwa dla osób znajdujących się $\mathrm{w}$ trudnej sytuacji życiowej (w tym przypadku chodzi o osoby bezdomne);

- fachowe doradztwo przy pozyskiwaniu pomocy finansowej i materialnej, rządowej, samorządowej i unijnej ze strony powołanych do tego instytucji;

- nauczenie się umiejętności podejmowania współpracy z innymi profesjonalistami oraz instytucjami zajmującymi się działaniami w sferze socjalnej i psychologicznej wobec osób dotkniętych bezdomnością;

- uczestnictwo w ustawicznym doskonaleniu etycznym i moralnym oraz dokształcaniu zawodowym;

- aktywne współuczestnictwo w procesie pomagania osobom bezdomnym w osiąganiu wysokiego poziomu jakości życia;

- teoretyczne i koncepcyjne przygotowanie oraz aktywne uczestnictwo w programach badawczych z dziedziny problemów bezdomności i osób bezdomnych;

- animowanie społecznych aktywności i inspirowanie działań samopomocowych na rzecz zaspokajania potrzeb osób bezdomnych ${ }^{22}$.

Kwalifikacje moralne i osobowościowe stanowią fundamentalny warunek i punkt wyjścia w podejmowaniu zawodowych zadań przez pracownika socjalnego.

\footnotetext{
${ }^{22}$ M. STEPUlaK, W. Kowalski, Zjawisko bezdomności w świetle teorii i badań w Lublinie $i$ województwie lubelskim, s. 103-104.
} 


\section{ZAWODOWE PROBLEMY PRACOWNIKA SOCJALNEGO W RELACJACH INTERPERSONALNYCH Z BEZDOMNYMI}

Ważnym zagadnieniem w pracy z bezdomnymi są dla pracownika socjalnego problemy zawodowe. Dlatego też rola i znaczenie działalności zawodowej pracownika socjalnego $\mathrm{w}$ relacjach $\mathrm{z}$ osobami bezdomnymi jest wyraźnie podejmowana w ustawach o pomocy społecznej. Najnowsza ustawa $\mathrm{z}$ dnia 8 lutego 2018 r. o zmianie ustawy o pomocy społecznej wprowadza następujący zapis: Art. 1. W ustawie z dnia 12 marca 2004 r. o pomocy społecznej (Dz.U. z 2017 r. poz. 1769 i 1985 oraz z 2018 r. poz. 650) wprowadza się m.in. następujące zmiany, które dotyczą pracownika socjalnego w odniesieniu do osób bezdomnych:

2g. Do wykonywania czynności w zakresie usług świadczonych w schronisku dla osób bezdomnych zatrudnia się:

1) pracowników socjalnych;

2) opiekunów posiadających co najmniej średnie wykształcenie oraz ukończone szkolenie z zakresu udzielania pierwszej pomocy.

$2 \mathrm{~h}$. Do wykonywania czynności w zakresie usług świadczonych w schronisku dla osób bezdomnych z usługami opiekuńczymi zatrudnia się:

1) pracowników socjalnych;

2) opiekunów posiadających:

a) kwalifikacje do wykonywania zawodu pielęgniarki, ratownika medycznego, opiekuna w domu pomocy społecznej, opiekuna osoby starszej, asystenta osoby niepełnosprawnej, opiekunki środowiskowej, opiekuna medycznego lub

b) udokumentowane co najmniej roczne doświadczenie zawodowe polegające na świadczeniu usług opiekuńczych osobom niepełnosprawnym, przewlekle chorym lub osobom w podeszłym wieku oraz ukończone szkolenie z zakresu udzielania pierwszej pomocy" 23 .

Pracownik socjalny musi mieć świadomość, iż wchodzenie w relacje interpersonalne $\mathrm{z}$ osobami bezdomnymi jest bardzo trudne, ale jednocześnie bardzo ważne. Powodem tego jest to, iż osoby bezdomne już we wczesnym okresie swojego życia doświadczały swoistej atomizacji w swoim naturalnym systemie rodzinnym. „Atomizacja w środowisku rodzinnym przejawia się wewnętrzną, własną izolacją psychiczną, zainteresowaniem swoimi problemami, samodzielnym rozwiązywaniem swoich trudności życiowych, edukacyj-

\footnotetext{
${ }^{23}$ Ustawa z dnia 8 lutego 2018 roku, Warszawa, poz. 700. Dz.U. 2018, poz. 700.
} 
nych, eksponowaniem wolności jednostki i jej samorealizacji. W środowisku rodzinnym zjawisko atomizacji wyraża się zarówno w sferach fizycznych, jak i psychicznych. Atomizacja oznacza, że każde z rodziców i dzieci przebywa najczęściej oddzielnie, realizując własne plany, zainteresowania i potrzeby. Nie mają oni potrzeby kontaktu społecznego, bliskości fizycznej drugiej osoby [...] Psychiczny dystans między rodzicami oraz rodzicami i dziećmi zagraża w znacznym stopniu więziom emocjonalnym we wspólnocie rodzinnej. Następuje oziębienie więzi społecznych i stosunków uczuciowych w środowisku rodzinnym" ${ }^{24}$. Zdarza się również, iż pracownik socjalny ma ogromne trudności w podjęciu relacji interpersonalnych z bezdomnymi matkami, które samotnie wychowuja swoje dzieci ${ }^{25}$.

Podstawowe zasady aktywności zawodowej wiążą się nierozerwalnie z zasadami etycznymi. W tym aspekcie można by wymienić następujące zasady postępowania pracownika socjalnego w odniesieniu do osób bezdomnych:

- Zasada działania dla dobra i nieszkodzenie osobom, z którymi pracują.

- Zasada wierności i odpowiedzialności. Istotnym elementem działalności zawodowej pracownika socjalnego jest stworzenie poczucia bezpieczeństwa, odpowiedzialne ugruntowanie wiedzy i praktyki, odpowiedzialna ocena własnych kompetencji zawodowych, odpowiedzialny rozwój zawodowy, odpowiedzialny wybór metody pracy, odpowiedzialność w zakresie nowo powstających metod, kompetencje w odniesieniu do grup szczególnych (bezdomnych), odpowiedzialne postępowanie w przypadku problemów osobistych. Odpowiedzialne postępowanie $\mathrm{w}$ sytuacji złożonych ról, odpowiedzialna ocena możliwości wymiany barterowej, odpowiedzialność za relacje seksualne w kontekście profesjonalnym, odpowiedzialna współpraca $\mathrm{z}$ innymi specjalistami, współodpowiedzialność za środowisko zawodowe pracowników socjalnych, odpowiedzialna postawa wobec konfliktu zasad etycznych z wymogami pracodawcy, odpowiedzialna postawa wobec konfliktu zasad etycznych z regulacjami prawnymi.

- Zasada uczciwości i prawości. Pracownik socjalny promuje uczciwość, precyzję i prawdę we wszystkich kontekstach swojej pracy zawodowej, istotna

${ }^{24}$ H. CUDAK, Makrospołeczne dysfunkcje a zagrożenia we wspótczesnej rodzinie, w: Tradycja i wspótczesne nurty $w$ opiece, wychowaniu i resocjalizacji w Europie, red. S. Bębas, E. Kielska, Wydawnictwo Wyższej Szkoły Handlowej, Radom 2014, s. 172.

${ }^{25}$ M. BARABAS, Postawy rodzicielskie bezdomnych matek samotnie wychowujacych dzieci - komunikat z badań, „Wychowanie na co Dzień” 2011, 3(210), s. 26-30. 
jest jego odpowiedzialność za wystąpienia w mediach, do tego dochodzi odpowiedzialność za stosowanie narzędzi diagnostycznych.

- Zasada sprawiedliwości. W aktywności zawodowej pracownika socjalnego niedopuszczalna jest dyskryminacja ze względu na wiek, płeć, identyfikację płciową, rasę, narodowość, religię, światopogląd, orientację płciową, niepełnosprawność, język czy status socjoekonomiczny.

- Zasada szacunku dla ludzkich praw i ludzkiej godności. Pracownik socjalny okazuje bezwzględny szacunek dla godności osoby ludzkiej, szacunek dla celów pacjenta, szacunek dla indywidualności i światopoglądu klienta, respektowanie prawa do prywatności ${ }^{26}$.

Podjęcie roli zawodowej pracownika socjalnego wiąże się $\mathrm{z}$ podjęciem wielu wyzwań. Nowe wyzwania w pracy z osobami bezdomnymi rozwijaja potencjał psychospołeczny pracownika socjalnego, ujawniaja jego predyspozycje, umiejętności, zdolności oraz kompetencje. „Możliwość realizowania się w roli zawodowej, czerpanie satysfakcji z wykonywanych, specyficznych dla niego czynności znajduje konsekwencje w jakości działań składających się na inne role społeczne wpisane w codzienne funkcjonowanie"27.

Ważnym elementem działalności zawodowej pracownika socjalnego jest poczucie tożsamości zawodowej. W tym przypadku można mówić o podejściu podmiotowym i przedmiotowym. W rozumieniu podmiotowym pracownik socjalny identyfikuje się z innymi ludźmi, odczuwa więź z nimi, uświadamia sobie więź ze wspólnotą oraz gotowość do działania. W rozumieniu przedmiotowym tożsamość zawodowa wyraża się poprzez dostrzeganie powiązań pomiędzy własną osobą i niektórymi ludźmi oraz odniesieniem do nich pojęcia „My”. Szczególną kategorią osób są ludzie bezdomni ${ }^{28}$.

Dla budowania tożsamości zawodowej pracownika socjalnego bardzo ważna jest jakość podejmowanych relacji interpersonalnych, które nasycone są empatią na linii: specjalista-bezdomny. W tym aspekcie można mówić o pewnych zdolnościach i umiejętnościach, które temu służą:

- Otwartość jako zdolność do chwilowego wyzbycia się własnych przekonań, postaw, wartości i przyjęcia tych, które należą do drugiej, bezdomnej osoby. Otwartość w takim przypadku staje się tym trudniejsza, im bardziej punkt widzenia osoby bezdomnej różni się od naszego.

${ }^{26}$ D. BEDNAREK, Zawód psycholog. Regulacje prawne i etyka zawodowa, Wydawnictwo Naukowe PWN, Warszawa 2016, s. 89-124.

${ }^{27}$ S. BYRA, M. PARCHOMIUK, Kompetencje spoteczne $w$ procesie aktywizacji zawodowej osób niepetnosprawnych, „Praca Socjalna” 26(2011), nr 2, s. 23.

${ }^{28}$ M.Z. Stepulak, Psycholog jako zawód zaufania spotecznego, s. 102. 
- Wyobraźnia, która jest bardzo ważna w budowaniu adekwatnych relacji interpersonalnych. Pracownik socjalny zatem powinien wyobrazić sobie położenie i sytuację osoby bezdomnej.

- Zaangażowanie jako autentyczna chęć zrozumienia przez pracownika socjalnego osoby bezdomnej. Do przyjęcia takiej postawy niezbędny jest wysoki poziom empatii u pracownika socjalnego ${ }^{29}$.

W obszarze relacji zawodowych niezbędne są odpowiednie kwalifikacje pracownika socjalnego. W czasie przygotowania zawodowego pracownik musi nauczyć się jak rozeznawać sytuację osobistą podopiecznych. Specjalista musi koniecznie uwzględniać dobro bezdomnego i starać się być uczciwym i prawym w swoim sumieniu. Istotną kwestią zawodowego rozwoju jest kształtowanie tożsamości zawodowej oraz poczucia wspólnoty z osobami bezdomnymi. Budując adekwatne relacje interdyscyplinarne z osobami bezdomnymi, pracownik socjalny zdobywa zaufanie innych osób, nie tylko bezdomnych, oraz daje wszystkim poczucie bezpieczeństwa.

Problematyka bezdomności jest tematem podejmowanym przez wielu badaczy z różnych dziedzin i dyscyplin naukowych, jednocześnie jest to temat pomijany przez rządzących państwami, zwłaszcza o wysokim poziomie rozwoju gospodarczego. Bezdomność bowiem jest dla tych ludzi problemem wstydliwym, a czasami kompromitującym, pokazującym ich bezradność lub ignorancję. Biorąc pod uwagę taki stan rzeczy, pojawia się ogromne wyzwanie polegające na skutecznym działaniu pracowników socjalnych $\mathrm{w}$ pracy $\mathrm{z}$ bezdomnymi. Do realizacji tego celu pracownik socjalny winien prezentować najwyższe standardy w obszarze kompetencji osobowościowych i zawodowych oraz kwalifikacji moralnych. Fundamentem skuteczności działania pracownika socjalnego jest postawa zaufania. Zaufanie nie odnosi się tylko do przestrzeni społecznej, w której pracownik socjalny potrafi porozumieć się z bezdomnym, ale odnosi się przede wszystkim do pełnej osobowej relacji na linii: pracownik socjalny-osoba bezdomna.

${ }^{29}$ R.B. AdLER, L.B. Rosenfeld, R.F. Proctor II, Relacje interpersonalne, Dom Wydawniczy Rebis, Poznań 2007, s. 97. 


\section{BIBLIOGRAFIA}

Adler R.B., Rosenfeld L.B., Proctor II R.F., Relacje interpersonalne, Dom Wydawniczy Rebis, Poznań 2007.

BARABAS M., Postawy rodzicielskie bezdomnych matek samotnie wychowujących dzieci komunikat z badań, „Wychowanie na co Dzień” 2011, nr 3 (210), s. 26-30.

BEDNAREK D., Zawód psycholog. Regulacje prawne i etyka zawodowa, Wydawnictwo Naukowe PWN, Warszawa 2016.

Byra M., PARChOMiUK S., Kompetencje społeczne w procesie aktywizacji zawodowej osób niepełnosprawnych, „Praca Socjalna” 26(2011), nr 2, s. 23-37.

CHAŃko A., O potrzebie poczucia koherencji u osób bezdomnych, „Praca Socjalna” 28(2013), s. $116-120$.

CUDAK H., Makrospołeczne dysfunkcje a zagrożenia we współczesnej rodzinie, w: Tradycja i współczesne nurty w opiece, wychowaniu i resocjalizacji w Europie, red. S. Bębas, E. Kielska, Wydawnictwo Wyższej Szkoły Handlowej, Radom 2014, s. 167-173.

DudA M., Bezdomność - wyzwanie moralne społeczeństwa, w: Przestrzenie pracy socjalnej, red. J. Stala, Biblos, Tarnów 2010, s. 373-385.

DURKHEIM E., Próba określenia zjawisk religijnych, „Biblioteka Samokształcenia”, Warszawa 1903.

GIEREK P., O ludziach niechcianych - wykluczonych i marginalizowanych, „Praca Socjalna” 25(2010), s. 22-53.

JAŹDZIKOwSKi M., Syndrom bezdomności, „Świat Problemów” 2000, nr 6(89), s. 4-7.

Kinal A., Bezdomność jako wyzwanie dla społeczności lokalnej, „Rocznik Lubuski” 29(2003), cz. 1, s. 193-206.

KLebaniuk J., Fenomen nierówności społecznych, ENETEIA, Wydawnictwo Psychologii i Kultury, Warszawa 2007.

KLEBAnIUK J., Oblicza nierówności społecznych, ENETEIA, Wydawnictwo Psychologii i Kultury, Warszawa 2007a.

KULKA B., Ludzie bezdomni - jak możemy im pomóc? w: Środowiska specjalnej troski, red. M. Kalinowski, Wydawnictwo POLIHYMNIA, Lublin 2003, s. 45-53.

KUSY M., Świat społeczny bezdomnych kobiet, „Praca Socjalna” 27(2012), s. 140-146.

LECH A., Świat społeczny bezdomnych i jego legitymizacje, Wydawnictwo Naukowe „Śląsk”, Katowice 2007.

PAŁCZYŃSKi J., Anomia, w: Słownik psychologii, red. J. Siuta, Wydawnictwo Zielona Sowa, Kraków 2005, s. 27.

PIECHOwICZ M., Bezdomność jako problem społeczny i indywidualny - możliwości profilaktyki, „Resocjalizacja Polska” 2012, nr 3, s. 327-340.

PoDGÓRSKA-JACHNIK D., Praca socjalna z osobami bezdomnymi, Centrum Rozwoju Zasobów Ludzkich, Warszawa 2014.

PosPISZYL I., Patologie społeczne, Wydawnictwo Naukowe PWN, Warszawa 2009.

SIERPOWSKA I., Sytuacja prawna osoby bezdomnej w Polsce, „Praca Socjalna” 26(2011), s. 84105.

SIKORA K., Dobro odbiorcy w kodeksach etyczno-zawodowych psychologów, „Roczniki Psychologiczne" 16(2013), nr 4, s. 587-601.

StepulaK M.Z., Kowalski W., Zjawisko bezdomności w świetle teorii i badań w Lublinie i województwie lubelskim, Innovatio Press Wydawnictwo Naukowe Wyższej Szkoły Ekonomii i Innowacji w Lublinie, Lublin 2015.

STEPUlAK M.Z., Psycholog jako zawód zaufania społecznego, TN KUL, Lublin 2007. 
STEPUlAK M.Z., Wybrane problemy etyczno-zawodowe w pracy socjalnej, Innovatio Press Wydawnictwo Naukowe Wyższej Szkoły Ekonomii i Innowacji w Lublinie, Lublin 2012.

AKTY PRAWNE

Ustawa z dnia 12 marca 2004 r. o pomocy społecznej (Dz.U. $2004 \mathrm{Nr} 64$ poz. 593).

Ustawa z dnia 8 lutego 2018 roku, Warszawa (Dz.U. 2018, poz. 700).

\title{
STRONY INTERNETOWE
}

http://ptps. ops.pl/kodeks_etyczny.htm (dostęp: 08.08.2018).

www.polsatnews.pl/wiadomosc/2017-03-09 (dostęp: 09.08.2018).

\section{PROBLEMY ETYCZNO-ZAWODOWE PRACOWNIKA SOCJALNEGO W PRACY Z OSOBAMI BEZDOMNYMI}

\author{
S t r e s z c z e n i e
}

W niniejszym artykule na początku została poddana naukowej refleksji problematyka bezdomności w aspekcie jej definicji, przyczyn oraz typologii. W dalszej kolejności przedmiotem naukowej analizy stały się etyczne i moralne problemy pracownika socjalnego w relacjach interpersonalnych z bezdomnymi. Zasady i normy etyczne zwarte są przede wszystkim w Kodeksie Etycznym Pracowników Socjalnych i Pracowników Pomocy Społecznej Polskiej Federacji oraz w Kodeksie Etycznym Polskiego Towarzystwa Pracowników Socjalnych. Do tego pracownik socjalny musi zrealizować wiele celów. Jednym z takich celów jest ustawiczne doskonalenie etyczne i moralne oraz doskonalenie osobowościowe. Drugim obszarem formacji pracownika socjalnego są kwalifikacje zawodowe, które zakładają realizację następujących zasad: a) zasada działania dla dobra i uszanowania podopiecznych; b) zasada wierności i odpowiedzialności; c) zasada uczciwości i prawości; d) zasada sprawiedliwości; e) zasada szacunku dla ludzkich praw i ludzkiej godności.

Słowa kluczowe: kompetencje zawodowe; kwalifikacje moralne; osoba bezdomna; pracownik socjalny; relacje interpersonalne. 